\title{
Identification and Incident Rate of Phylum Protozoa Around The Sad and Grazing Fields of Madura Cattle in Sub-District of Geger Bangkalan District
}

\author{
${ }^{1}$ Chikita Helvi Silvana Putri, ${ }^{2}$ Sarmanu, ${ }^{3)}$ Lilik Maslachah \\ ${ }^{1)}$ Student, Faculty of Veterinary Medicine, Universitas Airlangga, chikita.helvi.silvana- \\ 2019@fkh.unair.ac.id \\ ${ }^{2)}$ Division of Veterinary Anatomy, Faculty of Veterinary Medicine, Universitas Airlangga \\ ${ }^{3)}$ Division of Basic Veterinary Medicine, Faculty of Veterinary Medicine, Universitas Airlangga \\ Received: 15-08-2021, Accepted: 25-08-2021, Published Online: 30-09-2021 \\ Corresponding author: sarmanu@fkh.unair.ac.id
}

\begin{abstract}
This research aims to determine the percentage and kind of Phylum Protozoa contamination in around the sed and grazing field soil of Madura cattle in Sub-District of Geger, Bangkalan District. The research was conducted on March untul Mei 2019. The method of this research used a nonexperimental method and through an observation study. The sample of this research was 100 samples of around the sed and grazing field soil, then examined in the laboratory of Parasitology Airlangga University, Division of Veterinary Parasitology used Sucrose Floatation Method. The result showed that percentage of Phylum Protozoa was 53\%. Based on the type of soil, the highest contamination was Eimeria spp. (43\%), followed by Blastocystis sp. (24\%) and Isospora spp. (4\%). Based on location, the percentage of grazing fields was higher $(75 \%)$ than around the sad $(38.3 \%)$. The results of statistical analysis using Chi-square test showed significant differences in the percentage between contamination around of the cages and grazing field soil $(\mathrm{P}<0.05)$.
\end{abstract}

Keywords: around the shed soil, grazing field soil, Bangkalan District.

\section{Introduction}

Geger Sub-District is one area that has good prospects in the field of cattle farming. Based on data from the Directorate General of Livestock and Animal Health, Bangkalan District, in 2018 the population of cattle in Geger Sub-District reached 23,677 heads from 13 villages (Central Bureau of Statistics Bangkalan District, 2018).

The pattern of cattle development in Geger Sub-District, Bangkalan District in general is still traditional. Cattle are usually placed in simple cages, or tethered to trees. In terms of sanitation, livestock raising systems like this characterize traditional cultivation patterns. The construction of the cowshed for pen sanitation is not exist so that the livestock manure is dumped behind the cow, so the floor of the cage is only made higher, the floor is flat and the drainage channel is made.

According to Nugroho (2014), soil is very potential as a reservoir of human disease where the soil can carry and as a place to live various kinds of pathogenic microorganisms and the soil can store various sources of harmful pollutants. This is because soil is the recipient of solid waste, causing soil contamination which can contain harmful organic, inorganic and pathogenic microorganisms. Soil is a component that is formed naturally as a medium for the growth of living things, from plant species to microbes from other parasites (Prihastuti, 2011 in Azmy et al., 2015). There are several factors that influence the results of the soil sample examination, namely the location of the sample, the number of sample volumes, the depth of sampling, the season, identification methods, sample storage and laboratory skills (Sudhakar et al, 2015). Some things that make this research necessary are Geger Sub-District has the largest cattle population, namely 23,677 heads and the location of Geger Sub-District is in the highlands, causing humid temperatures (Central Bureau of Statistics Bangkalan District, 2018). Based on its geographical location, protozoa can survive in tropical climates with temperatures to live between $16-25^{\circ} \mathrm{C}$ with a maximum temperature between $30^{\circ} \mathrm{C}-40^{\circ} \mathrm{C}$ (Kurihara et al., 1978 in Diaz et al., 2016). Geographically, the location of Kompol Village, Geger Sub-District, includes hilly areas with an altitude of 17-182 meters above sea level and has a rainfall of $22.10 \mathrm{~mm} /$ day and a temperature of $25^{\circ} \mathrm{C}-33^{\circ} \mathrm{C}$, making it possible for the transmission of protozoa through the soil. So far there is no data regarding cases of protozoa that contaminate through the soil in Geger Sub- 
District, Bangkalan District, so that it is useful in efforts and controlling protozoal contamination. This study aims to determine the type of protozoa that contaminate the soil, the magnitude of the incidence and the difference in the incidence rate of the soil contaminated with protozoa around the cages and cattle grazing fields of Madura, Geger Sub-District, Bangkalan District.

\section{Materials and Methods}

The present study is survey observational study. The samples examined came from sandy soil taken from around the cages and grazing fields with a sampling distance of $\pm 10-20 \mathrm{~m}$ for each sample. The population of Madura cattle in Kompol Village was 1075 heads. The sample size calculated using the slovin formula shows that the minimum number of samples required is 91,489 samples which are rounded up to 100 , so that the required sample is 100 samples in locations around the stables and herding fields. The selection of the sampling technique is a research effort to obtain a representative sample that can describe the population. The examination was carried out at the Laboratory of the Division of Veterinary Parasitology, Faculty of Veterinary Medicine, Airlangga University. Samples were examined for the presence of protozoa by floating method using a saturated sugar solution. If the sample is found to be protozoa, then the sample is declared positive.

\section{Results and Discussion}

Based on laboratory examination by floating on 100 soil samples taken from the soil around the stables and grazing fields, 53 samples were positive and 47 samples were negative. In the study, the protozoa found were Eimeria spp., Blastocystis spp., and Isospora spp (Fig. 1).

The results of the chi square analysis showed that there were significant differences in the incidence of protozoal contamination around the stables and grazing fields. The place of collection has an effect on protozoal contamination. This shows that the soil in grazing fields has a higher risk of being found by protozoa than around the rearing cages.

Based on laboratory examination with Modified Sucrose Floatation Method on 100 soil samples consisting of 60 soil samples around the cages and 40 samples of grazing land, the prevalence was 53\%. Eimeria spp. was found from 43 soil samples. Blastocystis sp. found from 24 soil samples and Isospora spp. found from 4 soil samples.

Contamination of one genus around the cage was found by Eimeria spp., 10 positive samples, Blastocystis sp., 4 positive samples. Contamination of two genera was found Eimeria spp., and Blastocystis sp., as many as 9 positive samples. Contamination of one genus in the soil in grazing fields was found by Eimeria spp., 16 positive samples, Isospora spp., 2 positive samples, and Blastocystis sp., 3 positive samples. Contamination of two genera was found Eimeria spp., and Blastocystis sp., 7 positive samples were Eimeria spp., and Isospora spp., 1 sample, Blastocystis sp., and Isospora spp., 1 positive sample.

Protozoa identification is done by observing the morphology of the shape and size of the protozoa. Protozoa were measured and observed with a microscope connected to an optilab. Eimeria spp. was the main single infection, followed by Blastocystis spp., and the lowest single infection was Isospora spp. In the contamination of two genera, Eimeria spp. and Blastocystis spp. were the highest infections and the lowest mixed infections were Isospora sp. (Fig. 6).

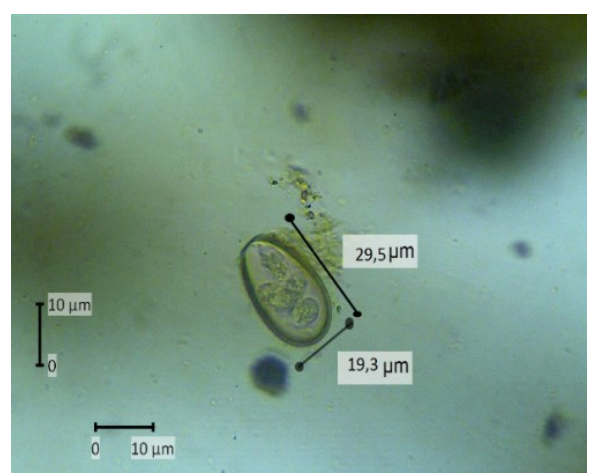

Figure 1. Oocysts of Eimeria spp. which were already sporulated. $\mathrm{M}=400 \mathrm{x}$.

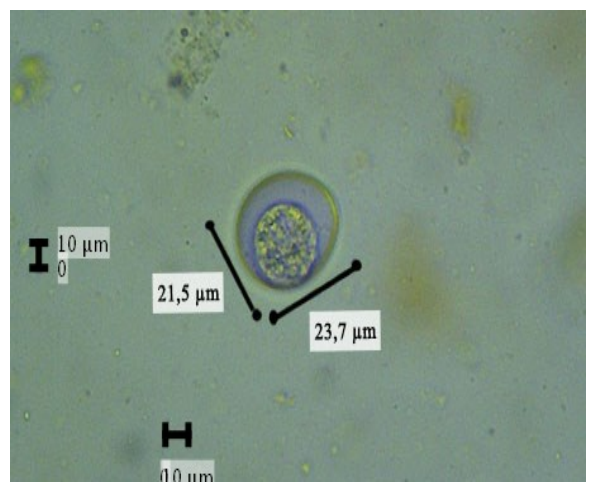

Figure 2. which has not experienced sporulation. $\mathrm{M}=400 \mathrm{x}$ 


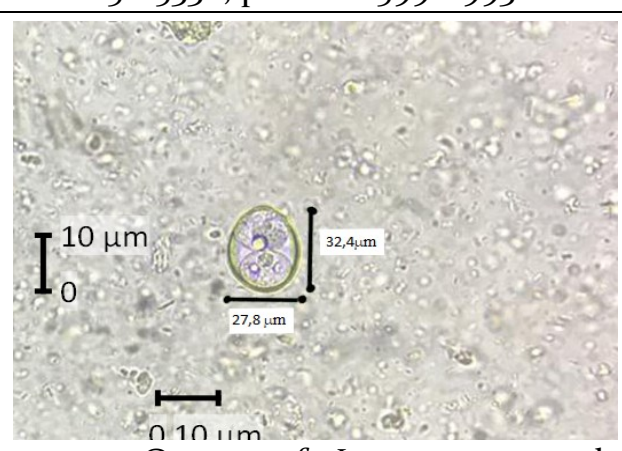

Figure 3. Oocyst of Isospora spp. clearly demarcated. $M=400 x$

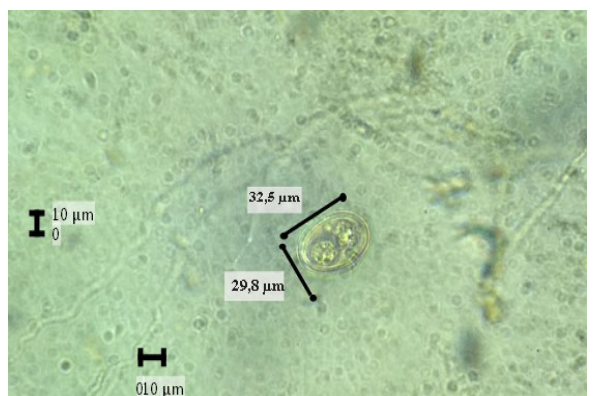

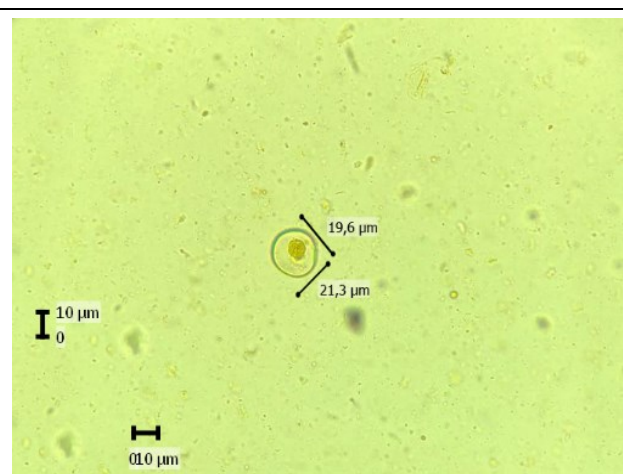

Figure 5. Cyst of Blastocystis sp. (E). 40ox magnification. $M=400 x$

Table 1. The kind of protozoa found contaminating the soil in Kompol Village, Geger Sub-District, Bangkalan District.

\begin{tabular}{c|c}
\hline Kind of Protozoa & Number \\
\hline Eimeria spp. & 43 \\
Blastocystis sp. & 24 \\
Isopora spp. & 4 \\
\hline
\end{tabular}

Figure 4. Oocyst of Isospora spp. has two sporocysts. $\mathrm{M}=400 \mathrm{x}$

Table 2. The kind of Protozoa on soil found based on the location of maintenance in Kompol Village, Geger Sub-District, Bangkalan District

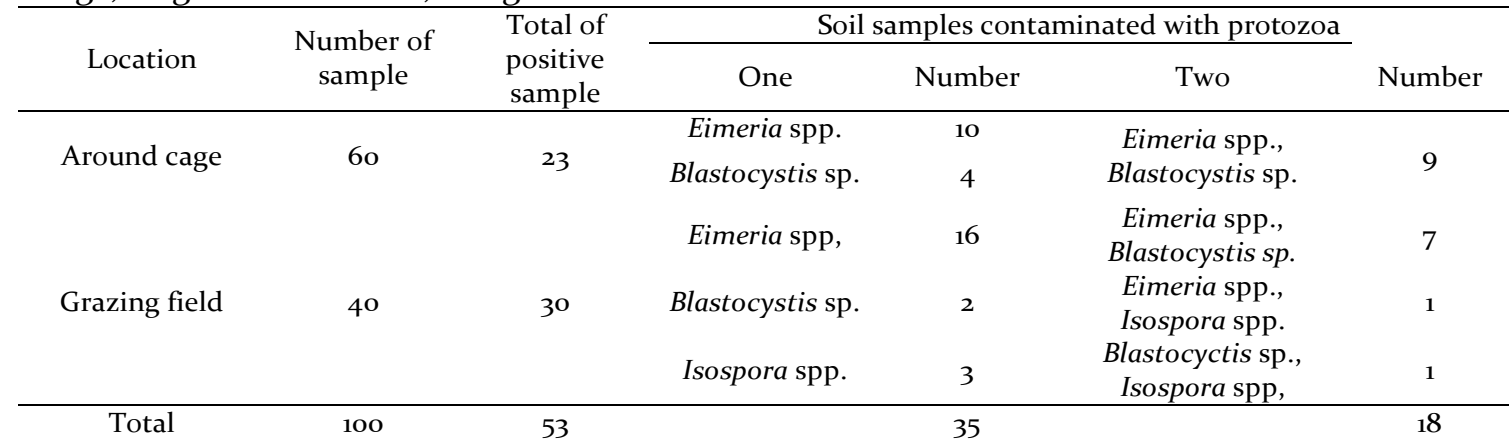

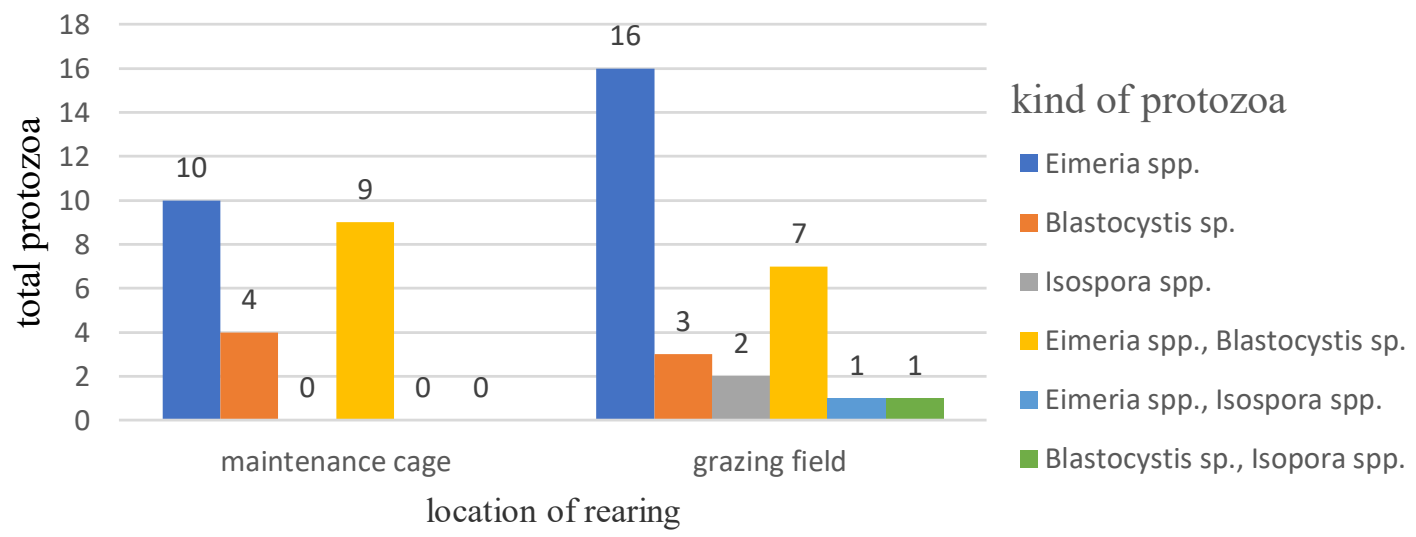

Figure 6. Protozoal Contamination Load on soil contaminated by protozoa around stables and grazing fields. 
Based on the rearing location, the comparison of contamination around the cages and Madura cattle grazing fields was obtained in Kompol Village, Geger Sub-District, Bangkalan District. The genus Eimeria spp. was found in two rearing locations, around the cages 10 positive samples were obtained, while in the grazing fields, 16 positive samples were obtained. The genus Blastocystis sp. also found in two rearing locations, around the cages, four positive samples were obtained, while in the grazing fields three positive genera were found. The genus Isospora spp. in the rearing cage was not found while in the grazing field 2 positive samples were found. In the two rearing locations, contamination of two genera was also found, around the cage only Eimeria spp. and Blastocystis spp. contamination were found, as many as 9 positive samples, while in grazing fields there were seven positive samples. Contamination of two genera Eimeria spp., and Isospora spp., was not found around the cages, while one positive sample was found in the grazing fields. Contamination of two genera Blastocystis spp., and Isospora spp., was only found in grazing fields as much as one positive sample.

Table 3. The results of the cross tabulation comparison of rearing locations around the cages and Madura cattle grazing fields in Geger Sub-District, Bangkalan District.

\begin{tabular}{clccc}
\hline & & \multicolumn{2}{c}{ cage system } & \\
\cline { 3 - 4 } & & $\begin{array}{c}\text { Around } \\
\text { Cage }\end{array}$ & $\begin{array}{c}\text { Grazing } \\
\text { Field }\end{array}$ & $\begin{array}{c}\text { Tota } \\
1\end{array}$ \\
\hline \multirow{2}{*}{ Resul } & Positive & 23 & 37 & 60 \\
$\mathrm{t}$ & Negative & 37 & 10 & 40 \\
& Incident & 38.33 & 75 & 100 \\
& Rate (\%) & & & \\
\hline
\end{tabular}

Statistical analysis using $2 \times 2$ cross tabulation showed the incidence of protozoa contaminating the soil around the cages and Madura cattle grazing fields, a significance value of o.oo1 was obtained which showed a significant difference $(\mathrm{p}<0.05)$.

Moist areas are good conditions for the growth of various types of worms and protozoan parasites. Another factor that makes the percentage of protozoa contamination high is the state of the soil. In addition, when sampling was carried out in early March in the rainy season, the environmental and soil conditions became more humid, so the percentage became higher (Kusnoto et al., 2014). During the rainy season, the soil becomes loose around the grazing fields in Geger Sub-District. The resistance of the infective stage of the protozoa in the environment also increases so that the protozoa can survive for some time. The effect of location on protozoa contamination in the soil around the stables and grazing fields was calculated by statistical analysis of the Chi square test by calculating the magnitude of the risk analysis obtained a value of 0.001 which indicates that there was an effect of the location of maintenance on contamination due to the value $(\mathrm{P}<0.05)$. This shows that the protozoan contamination of the grazing land has a double chance of contamination compared to the soil around the rearing cage. The high prevalence of protozoa in grazing fields in Kompol Village, Geger Sub-District, Bangkalan District was thought to be because cows rarely or almost never do grazing rotations, this is due to several factors, namely farmers who are old, or prefer to be tied to tree trunks in the grazing fields.

\section{Conclusions}

Based on the results of the study, it can be concluded that from 100 soil samples obtained 53 positive samples of soil contaminated with protozoa with a percentage of $53 \%$. the percentage contamination around of the cages was lower than and grazing field soil.

\section{References}

Azmy, A. A., Ida Ayu P.A., Apsara dan Ida Bagus K.A. 2015. Isolasi dan Identifikasi Oosista Koksidia dari Tanah Di Sekitar Tempat Pembuangan Sampah di Kota Denpasar: Indonesia Medicus Veterinus 4(2) : 163-169.

Prihastuti. 2011. Struktur Komunitas Mikroba Tanah dan Implikasinya dalam Mewujudkan Sistem Pertanian Berkelanjutan. Jurnal El-hayah 1(4): 174181.

Sudhakar, N. R., S. Samanta, S. Sahu, O. K. Raina, S.C. Gupta, D. N. Madhu, and A. Kumar. 2013. Prevalence of Toxocara species eggs in soil samples of public health importance in and around Bareilly, Uttar Pradesh, India. Vet World 6(2): 88-89. 